\title{
A comparative study on the effect of salt stress on seed germination and early seedling growth of two Hibiscus species
}

\author{
Rashmi Gadwal and G.R. Naik* \\ Department of Biotechnology, Gulbarga University, Gulbarga- 585106, Karnataka, India.
}

\begin{abstract}
Hibiscus cannabinus and Hibiscus sabdariffa are two economically important plants from Malvaceae family. The germination and growth of plant is an important phonological stage, where the plants survival depends to it, especially in the saline conditions. Salinity tolerance in the arid and semiarid regions is one of the most important factors that effect on the agricultural production. The ability of seeds to germinate at high salt concentration in the soil is crucial importance for the survival and perpetuation of many plant species. Present study was carried out to test the effects of different salinity levels on germination and early seedling growth of Hibiscus cannabinus and Hibiscus sabdariffa, seedlings collected from different populations. The experiment was carried out using completely randomized design in three replication. Experimental treatment includes four levels of sodium chloride concentrations $(-0.05 \mathrm{MPa},-0.15 \mathrm{MPa},-0.30 \mathrm{MPa}$ and $-0.49 \mathrm{MPa})$. The results showed rate of germination, radicle, hypocotyl and plumule length, moisture content, fresh wet and dry seedling weights and seed viability index were higher in control treatment when compared to treated seeds. At $0.15 \mathrm{MPa}$ and more concentration, germination decreased significantly. This reduction in germination indicates that seeds of Hibiscus cannabinus showed more resistant to salt stress when compared to Hibiscus sabdariffa.
\end{abstract}

Key words: Biomass, Hibiscus cannabinus, Hibiscus sabdariffa, Germination, $\mathrm{NaCl}$, salt stress \& seedling,

\section{Introduction}

Indian agriculture has gone through a major revolution and the goal was achieved by use of high yielding varieties of crops that require frequent irrigation and application of fertilizers and pesticides. With this progress, the problems like salinity have also threatened the agriculture. Nearly half of the irrigated land and $20 \%$ of the world's cultivated land are currently affected by salinity [1]. Salt-affected soils are distributed throughout the world and no continent is free from the problem [2]. Globally, a total land area of 831 million hectares is salt affected.

Salinity is a continuing problem in the arid and semi-arid tracts of the world. It could be alleviated using irrigation management and/or crop management. However, the former approach is outdated and very expensive. Nevertheless, the latter is economical as well as efficient and it enables to produce salt tolerant crop lines. But prior to that there is a need to confirm the presence of genetically based variation for salt tolerance among different species or varieties of a particular crop at different growth stages.

Speed of germination and emergence is an important determinant of successful crop establishment [3]. Soil salinity may influence the germination of seeds either by creating an osmotic potential external to the seed preventing water uptake, or the toxic effects of $\mathrm{Na}+$ and $\mathrm{Cl}$ - ions on the germinating seeds [4]. Salt and osmotic stresses are responsible for both inhibition or delayed seed germination and seedling establishment [5]. Under these stresses, there is a decrease in water uptake during imbibition; furthermore, salt stress may cause excessive uptake of ions [6].

The genus Hibiscus has more than 300 species which are distributed throughout tropical and subtropical regions of the world. Most Hibiscus species are used as ornamental plants, but many are believed to have certain medicinal properties; among them are Hibiscus cannabinus and Hibiscus sabdariffa. These are common wild plant and thought to be native to Asia or tropical Africa and are the shrubs belonging to the family Malvaceae. The plant is rich in phytochemicals and many parts of the plant, including seeds, leaves, fruits and roots, are used in various foods and beverages as well as having a multitude of health benefits. Seeds from these plants are used for oil extraction, the rest being used as feed. The oil is suitable as a lubricant and for illumination, for manufacture of soap, linoleum and in paints and varnishes. The plants are grown in the marginal lands in India and has shown tolerance to stress condition. Thus, these plants can be a good candidate species for farming on saline lands.

The objective of the present study was to study the effects of salinity on the germination and seedling growth of Hibiscus cannabinus and Hibiscus sabdariffa at various sodium chloride $(\mathrm{NaCl})$ concentrations. There are no reports seen in the studies of these plants to ascertain the limits of salt tolerance and its biochemical basis. 


\section{Materials And Methods}

\subsection{Experimental design}

Healthy and uniform seeds of Hibiscus cannabinus and Hibiscus sabdariffa were procured from 10 local research station. Seeds were stored in sterilized polythene bags to avoid contamination. Seed germination bioassay was used to test the effect of salt $(\mathrm{NaCl})$ stress on the Hibiscus cannabinus and Hibiscus sabdariffa seeds under laboratory conditions. Seeds of Hibiscus cannabinus and Hibiscus sabdariffa were thoroughly washed with tap water to remove dirt and empty and undeveloped seeds. Seeds were surface sterilized with $0.1 \%$ mercuric chloride solution for $5 \mathrm{~min}$ and then washed $6-7$ times with distilled water. Four salinity concentrations ( 0 as control), $(-0.05 \mathrm{MPa},-0.15 \mathrm{MPa},-0.30 \mathrm{MPa}$ and $-0.49 \mathrm{MPa})$ of $\mathrm{NaCl}$ were used based on a preliminary test for salt tolerance of the species. Seeds were germinated in two folds of Whattman filter paper number 1 placed in $9 \mathrm{~cm}$ diameter petridishes with $5 \mathrm{ml}$ of test solution. Three replicates of 10 seeds each were used for each treatment. A seed was considered to have germinated at the emergence of the radical [7]. The germinated seeds were recorded regularly. Germination was started after $48 \mathrm{hrs}$ and continued until the seventh day of experiment. The seed was considered to have germinated when both the plumule and radicle had emerged $1 \mathrm{~mm}$. The seventh day old seedlings were randomly selected from each petri dish and their average length was measured. Finally, they were oven-dried at $65^{\circ} \mathrm{C}$ for $24 \mathrm{hrs}$ to measure their mean dry weight [8].

\subsection{Determination of Growth parameters}

Different growth parameters such as germination percentage, germination rate, seedling (radicle, hypocotyl and plumule) length, seedling vigour index, fresh weight, dry weight and moisture content were determined in control and for treatment.

Vigour index of the seedlings was estimated according to the formula [9].

Seedling Vigour index $=$ Total seedling length $(\mathrm{mm}) \mathrm{x}$ germination percentage $/ 100$

Statistical analysis: Data analysis was carried out by GraphPad Instat (version 3.10, Inc 2009) statistical software where one way analysis of variance (ANOVA) and mean values were compared by using Turkey's multiple comparision test at $5 \%$ probability level.

\section{Results And Discussion}

Salinity is the most widespread abiotic stress and constitutes the most stringent factor in limiting plant distribution and productivity. Effect of different concentrations of $\mathrm{NaCl}(-0.05 \mathrm{MPa},-0.15 \mathrm{MPa},-0.30 \mathrm{MPa}$ and $0.49 \mathrm{MPa}$ ) was studied on the germination, seedling growth, vigour index and biomass.

\subsection{Seed germination and growth}

Seed germination is one of the most important phases in the life cycle of plant and is highly responsive to existing environment. In both cases, higher seed germination and vigour index was observed in control in comparison to the treatment. Seedlings of Hibiscus cannabinus and Hibiscus sabdariffa showed significant reduction in different growth parameters studied i.e. seed germination, length of radicle, hypocotyl and plumule, Plant length, vigour index, moisture content, fresh and dry weight of both the seedlings with $-0.15 \mathrm{MPa} \mathrm{NaCl}$ concentration (Table 1, Table 2 and Fig. 1-9). The inhibitory effect of salinity stress was proportional to the exposure period and salt concentration. The rate of inhibition of germination and growth parameters of two plants was in order: $-0.15 \mathrm{MPa}>-0.05 \mathrm{MPa}$. Maximum reduction $(60.00 \%$ and $100 \%)$ in seed germination was observed with $-0.15 \mathrm{MPa} \mathrm{NaCl}$ solution at $24 \mathrm{hrs}$ of Hibiscus cannabinus and Hibiscus sabdariffa, respectively. Seedlings of two plants exhibited higher vigour index in control whereas significant reduction in vigour index was observed with $-0.05 \mathrm{MPa}$ and $-0.15 \mathrm{MPa} \mathrm{NaCl}$ solution.

The decrease in radical, hypocotyl, plumule length, vigour index and biomass was the manifestation of impaired metabolic activities due to the $\mathrm{NaCl}$ stress. The growth inhibition caused by different concentrations of $\mathrm{NaCl}$ solution is due to interference with plant growth processes like cell division and cell enlargement, inhibition in nutrient uptake, reduction in dry matter production due to inhibition of metabolic processes such as photosynthesis and respiration [10].

Means comparison for these traits showed that the application of $-0.15 \mathrm{MPa}$ salinity resulted in the loss of seedling length, seedling weight, germination percentage, germination rate and seed viability index of Hibiscus cannabinus as compared to control treatment (0 MPa salinity). Where there is no growth in the salinity treatment of $-0.30 \mathrm{MPa}$ and $-0.49 \mathrm{MPa}$ of both the plants.

In the present study, the effect of salinity stress on germination and different growth parameters were carried out for Hibiscus cannabinus and Hibiscus sabdariffa. The Hibiscus cannabinus was found to be more resistant when compared to Hibiscus sabdariffa.

At $1 \%$ salinity stress, reduction percentage of Hibiscus cannabinus for root length, hypocotyl length, plumule length and seedling length was found to be $81.55 \%, 90.37 \%, 69.02 \%$ and $81.23 \%$, respectively. Where 
as in case of Hibiscus sabdariffa, reduction percentage was observed to be $95.95 \%, 99.95 \%, 100 \%$ and $100 \%$. Similarly, fresh weight, dry weight, moisture content and seed viability index, the reduction percentage of Hibiscus cannabinus was found to be $66.87 \%, 53.22 \%, 38.07 \%$ and $92.35 \%$, respectively and reduction percentage of $100 \%, 81.39 \%, 100 \%$ and $100 \%$ was observed in Hibiscus sabdariffa (Table 3).

However, the most reduction in seedling length related to salinity level of $-0.15 \mathrm{MPa}$ and $-0.30 \mathrm{MPa}$ but it should be noted that levels $-0.30 \mathrm{MPa}$ and $-0.49 \mathrm{MPa}$ had no significant differences (no growth). In this relation, it can be said that salinity decrease radicle and plumule growth. Salinity, which is a result of osmotic pressure leads to reduction in water absorbance so there is reduction in cell division and differentiation leading to reduction of plumule and radicle length which will be explainable. Also the high sensitivity of seedling length to salinity stress may be attributed to the reduced transition of nutrients from cotyledons to caulicle under saline condition [11]. Moreover, saline condition disturbs water uptake by seed, resulting in the reduction of plant hormones and enzymes production which consequently inhibits seedling's growth [11, 12]. This finding is also supported by Neumann (1995) where he reported that salinity can rapidly inhibit root growth and hence capacity of water uptake and essential mineral nutrition from soil [13]. In plants, salt stress causes reduced cell turgor and depressed rates of root and shoot elongation [14], suggesting that environmental salinity acts primarily on water uptake. Furthermore, high intracellular concentrations of both $\mathrm{Na}+$ and $\mathrm{Cl}-$ can inhibit the metabolism of dividing and expanding cells [15], retarding germination and even leading to seed death. Also $\mathrm{NaCl}$ may be inhibitory to the activities of some enzymes that may play critical roles in seed germination [16]. There are many reports which are in agreement with the present findings indicating that salinity stress severely reduces seed germination and early seedling growth in safflower [17, 18] and other species such as triticale [18] and chickpea [19]. Similar result was observed by Chauhan and Johnson (2009) that the seed germination of jungle rice (E. colona) decreased linearly with increasing the $\mathrm{NaCl}$ concentration [20]. In addition, Ghazizade et al. (2012) showed a significant reduction of seedling length, fresh weight and dry weight was observed due to salt stress for all of the studied genotypes [21]. Also, Riti Thapar Kapoor (2011) in the study of Salinity - Induced Changes in Germination, Biomass and Physiological Characteristics of Oryza sativa L reported that germination and early seedling growth was decreased by increasing salinity stress in Oryza sativa plant [22]. Along with, Amiri et al. (2010) in study of effect of salinity stress on germination and seedling growth indices of Cynara scoolymus and Echinacea purpurea reported that seedling dry weight was decreased by increasing salinity stress in both medicinal plants [23].

Table 1: Means comparison of the effect of salinity stress on germination and growth parameters of Hibiscus cannabinus.

\begin{tabular}{|c|c|c|c|c|c|c|c|c|c|}
\hline $\begin{array}{l}\text { Salinity } \\
\text { Levels } \\
(\mathbf{M P a})\end{array}$ & $\begin{array}{c}\text { RL } \\
(\mathbf{c m})\end{array}$ & $\begin{array}{c}\text { HL } \\
(\mathbf{c m})\end{array}$ & $\begin{array}{c}\text { PL } \\
(\mathbf{c m})\end{array}$ & $\begin{array}{c}\text { Seedling } \\
\text { length }(\mathbf{c m})\end{array}$ & GR $(\boldsymbol{\%})$ & $\begin{array}{c}\text { MC } \\
(\boldsymbol{\%})\end{array}$ & $\begin{array}{c}\text { PWW } \\
(\mathbf{g m})\end{array}$ & $\begin{array}{c}\text { PDW } \\
(\mathbf{g m})\end{array}$ & $\begin{array}{c}\text { SVI } \\
(\boldsymbol{\%})\end{array}$ \\
\hline 0 & $6.83 \pm 0.48 \mathrm{a}$ & $3.95 \pm 0.12 \mathrm{a}$ & $1.00 \pm 0.00 \mathrm{a}$ & $11.78 \pm 0.50 \mathrm{a}$ & $100.0 \pm 0.000 \mathrm{a}$ & $0.2 \pm 0.02 \mathrm{a}$ & $0.13 \pm 0.005 \mathrm{a}$ & $0.11 \pm 0.008 \mathrm{a}$ & $11.78 \pm 0.67 \mathrm{a}$ \\
\hline-0.05 & $2.55 \pm 0.15 \mathrm{~b}$ & $2.63 \pm 0.14 \mathrm{~b}$ & $0.55 \pm 0.003 \mathrm{~b}$ & $5.73 \pm 0.27 \mathrm{~b}$ & $96.66 \pm 0.875 \mathrm{a}$ & $0.1 \pm 0.01 \mathrm{~b}$ & $0.12 \pm 0.006 \mathrm{~b}$ & $0.93 \pm 0.012 \mathrm{~b}$ & $5.50 \pm 0.25 \mathrm{~b}$ \\
\hline-0.15 & $1.26 \pm 0.10 \mathrm{c}$ & $0.59 \pm 0.00 \mathrm{c}$ & $0.35 \pm 0.053 \mathrm{c}$ & $2.21 \pm 0.15 \mathrm{c}$ & $40.00 \pm 2.626 \mathrm{c}$ & $0.09 \pm 0.0 \mathrm{c}$ & $0.05 \pm 0.004 \mathrm{c}$ & $0.06 \pm 0.008 \mathrm{c}$ & $0.88 \pm 0.065 \mathrm{c}$ \\
\hline-0.30 & $0.00 \pm 0.00 \mathrm{~d}$ & $0.00 \pm 0.00 \mathrm{~d}$ & $0.00 \pm 0.000 \mathrm{~d}$ & $0.00 \pm 0.00 \mathrm{~d}$ & $0.00 \pm 0.000 \mathrm{~d}$ & $0.0 \pm 0.00 \mathrm{~d}$ & $0.00 \pm 0.000 \mathrm{~d}$ & $0.00 \pm 0.000 \mathrm{~d}$ & $0.00 \pm 0.000 \mathrm{~d}$ \\
\hline-0.49 & $0.00 \pm 0.00 \mathrm{~d}$ & $0.00 \pm 0.00 \mathrm{~d}$ & $0.00 \pm 0.000 \mathrm{~d}$ & $0.00 \pm 0.00 \mathrm{~d}$ & $0.00 \pm 0.000 \mathrm{~d}$ & $0.0 \pm 0.00 \mathrm{~d}$ & $0.00 \pm 0.000 \mathrm{~d}$ & $0.00 \pm 0.000 \mathrm{~d}$ & $0.00 \pm 0.000 \mathrm{~d}$ \\
\hline
\end{tabular}

Note: Means of traits at each column with similar letters did not have any significant statistical difference.

$\mathrm{a}, \mathrm{b}, \mathrm{c}, \mathrm{d}$ Different superscripts in a raw differ significantly

RL: Radicle length, HL: Hypocotyl length, PL: Plumule length, GR: Germination rate, PWW: Plant wet weight,

PDW: Plant dry weight, SVI: Seedling viguor index.

Table 2: Means comparison of the effect of salinity stress on germination and growth parameters of Hibiscus sabdarifffa.

\begin{tabular}{|c|c|c|c|c|c|c|c|c|c|}
\hline $\begin{array}{l}\text { Salinity } \\
\text { Levels } \\
(\mathbf{M P a})\end{array}$ & $\begin{array}{c}\text { RL } \\
(\mathbf{c m})\end{array}$ & $\begin{array}{c}\text { HL } \\
\mathbf{( c m})\end{array}$ & $\begin{array}{c}\text { PL } \\
\mathbf{( c m})\end{array}$ & $\begin{array}{c}\text { Seedling } \\
\text { length }(\mathbf{c m})\end{array}$ & GR (\%) & $\begin{array}{c}\text { MC } \\
\mathbf{( \% )}\end{array}$ & $\begin{array}{c}\text { PWW } \\
(\mathbf{g m})\end{array}$ & $\begin{array}{c}\text { PDW } \\
(\mathbf{g m})\end{array}$ & $\begin{array}{c}\text { SVI } \\
(\mathbf{\%})\end{array}$ \\
\hline 0 & $3.96 \pm 0.38 \mathrm{a}$ & $6.13 \pm 0.11 \mathrm{a}$ & $1.10 \pm 0.00 \mathrm{a}$ & $11.30 \pm 0.50 \mathrm{a}$ & $100.0 \pm 0.000 \mathrm{a}$ & $0.2 \pm 0.02 \mathrm{a}$ & $0.16 \pm 0.005 \mathrm{a}$ & $0.10 \pm 0.008 \mathrm{a}$ & $10.78 \pm 0.67 \mathrm{a}$ \\
\hline-0.05 & $1.67 \pm 0.05 \mathrm{~b}$ & $1.41 \pm 0.12 \mathrm{~b}$ & $0.09 \pm 0.003 \mathrm{~b}$ & $4.10 \pm 0.27 \mathrm{~b}$ & $80.00 \pm 0.875 \mathrm{a}$ & $0.1 \pm 0.01 \mathrm{~b}$ & $0.94 \pm 0.006 \mathrm{~b}$ & $0.03 \pm 0.012 \mathrm{~b}$ & $3.50 \pm 0.25 \mathrm{~b}$ \\
\hline-0.15 & $0.06 \pm 0.10 \mathrm{c}$ & $0.02 \pm 0.00 \mathrm{c}$ & $0.08 \pm 0.023 \mathrm{c}$ & $1.21 \pm 0.15 \mathrm{c}$ & $00.00 \pm 0.000 \mathrm{c}$ & $0.09 \pm 0.0 \mathrm{c}$ & $0.05 \pm 0.004 \mathrm{c}$ & $0.02 \pm 0.008 \mathrm{c}$ & $0.08 \pm 0.065 \mathrm{c}$ \\
\hline-0.30 & $0.00 \pm 0.00 \mathrm{~d}$ & $0.00 \pm 0.00 \mathrm{~d}$ & $0.00 \pm 0.000 \mathrm{~d}$ & $0.00 \pm 0.00 \mathrm{~d}$ & $0.00 \pm 0.000 \mathrm{~d}$ & $0.0 \pm 0.00 \mathrm{~d}$ & $0.00 \pm 0.000 \mathrm{~d}$ & $0.00 \pm 0.000 \mathrm{~d}$ & $0.00 \pm 0.000 \mathrm{~d}$ \\
\hline-0.49 & $0.00 \pm 0.00 \mathrm{~d}$ & $0.00 \pm 0.00 \mathrm{~d}$ & $0.00 \pm 0.000 \mathrm{~d}$ & $0.00 \pm 0.00 \mathrm{~d}$ & $0.00 \pm 0.000 \mathrm{~d}$ & $0.0 \pm 0.00 \mathrm{~d}$ & $0.00 \pm 0.000 \mathrm{~d}$ & $0.00 \pm 0.000 \mathrm{~d}$ & $0.00 \pm 0.000 \mathrm{~d}$ \\
\hline
\end{tabular}

Note: Means of traits at each column with similar letters did not have any significant statistical difference.

a,b,c,d Different superscripts in a raw differ significantly

RL: Radicle length, HL: Hypocotyl length, PL: Plumule length, GR: Germination rate, PWW: Plant wet weight,

PDW: Plant dry weight, SVI: Seedling viguor index.

Table 3: Reduction percentage of the effect of salinity stress on germination and growth parameters of Hibiscus cannabinus and Hibiscus sabdariffa 


\begin{tabular}{|l|c|c|c|c|}
\hline \multirow{2}{*}{ Parameters } & \multicolumn{2}{|c|}{ Hibiscus cannabinus } & \multicolumn{2}{c|}{ Hibiscus sabdariffa } \\
\cline { 2 - 5 } & $\mathbf{- 0 . 0 5}(\mathbf{M P a})$ & $\mathbf{- 0 . 1 5}(\mathbf{M P a})$ & $\mathbf{- 0 . 0 5}(\mathbf{M P a})$ & $\mathbf{- 0 . 1 5}(\mathbf{M P a})$ \\
\hline Root Length & $62.66 \%$ & $81.55 \%$ & $57.82 \%$ & $95.95 \%$ \\
\hline Hypocotyl Length & $57.09 \%$ & $90.37 \%$ & $64.30 \%$ & $99.49 \%$ \\
\hline Plumule Length & $20.35 \%$ & $69.02 \%$ & $45.00 \%$ & $100 \%$ \\
\hline Seedling Length & $51.35 \%$ & $81.23 \%$ & $63.27 \%$ & $100 \%$ \\
\hline Fresh weight & $25.00 \%$ & $66.87 \%$ & $27.69 \%$ & $100 \%$ \\
\hline Dry weight & $32.25 \%$ & $53.22 \%$ & $18.60 \%$ & $81.39 \%$ \\
\hline Moisture content & $24.35 \%$ & $38.07 \%$ & $26.12 \%$ & $100 \%$ \\
\hline SVI & $53.05 \%$ & $92.35 \%$ & $70.84 \%$ & $100 \%$ \\
\hline
\end{tabular}

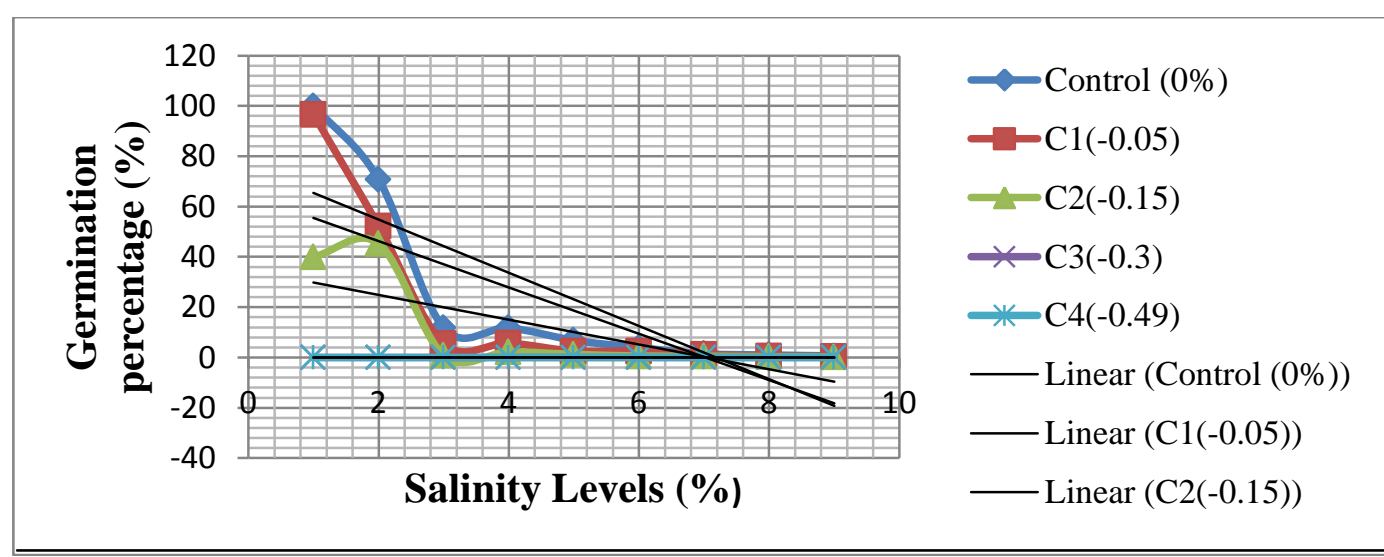

Graph1. Effect of different levels of salinity levels of germination percentage on H.cannabinus

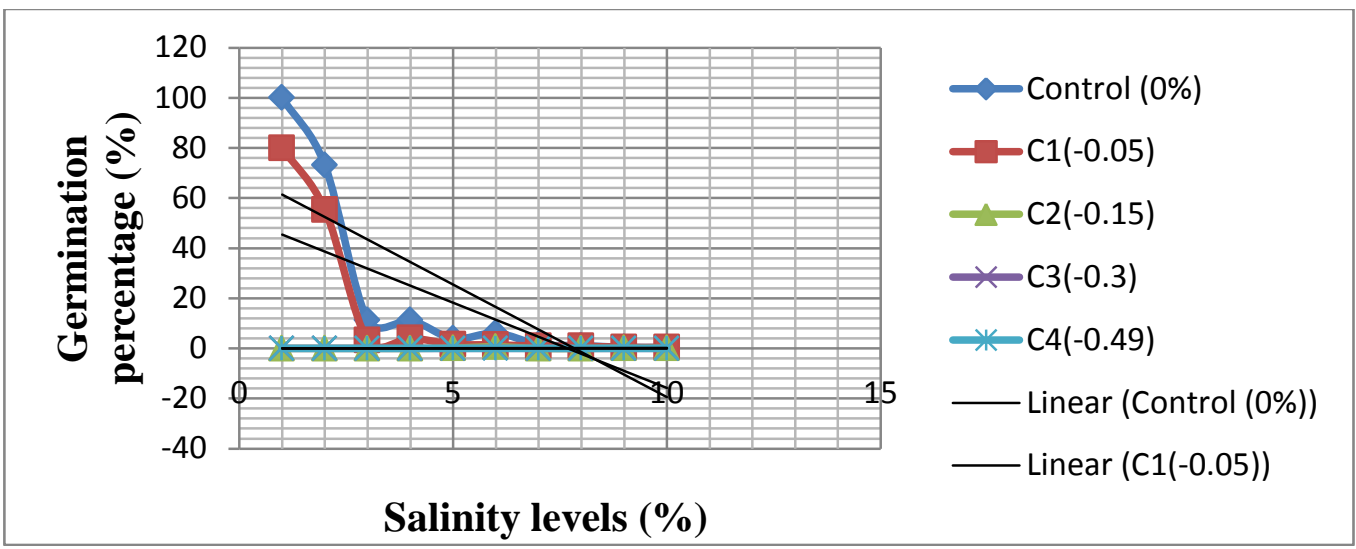

Graph2. Effect of different levels of salinity levels of germination percentage on H.sabdariffa

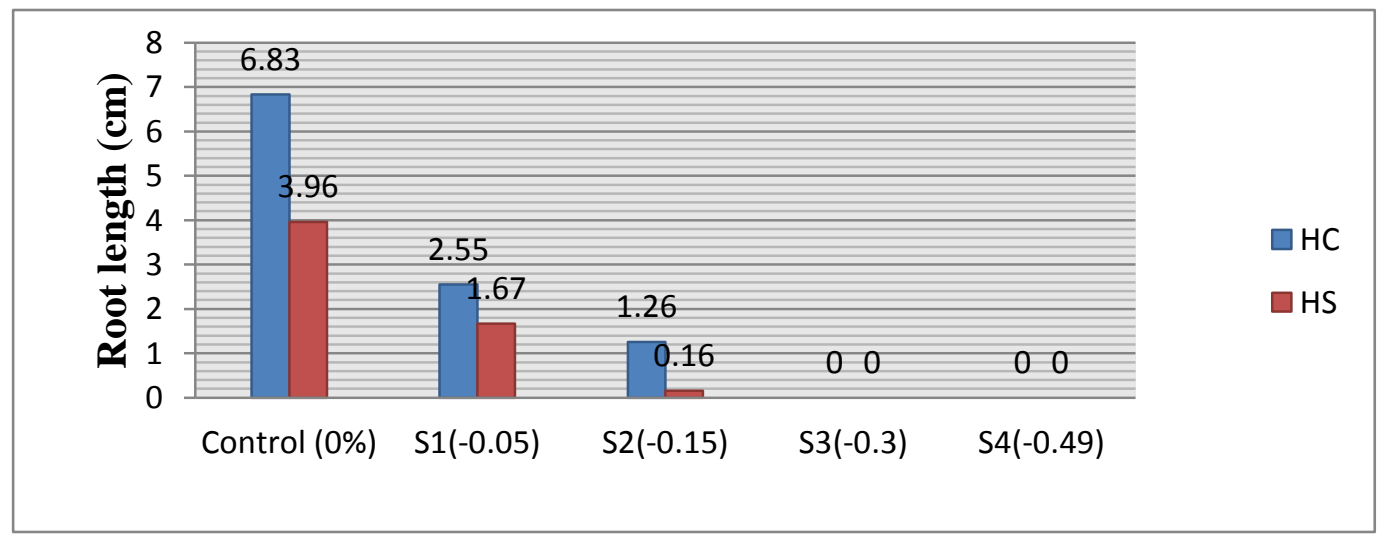

Graph3. Effect of different levels of salt stress on root length of H.cannnabinus and H.sabdariffa 


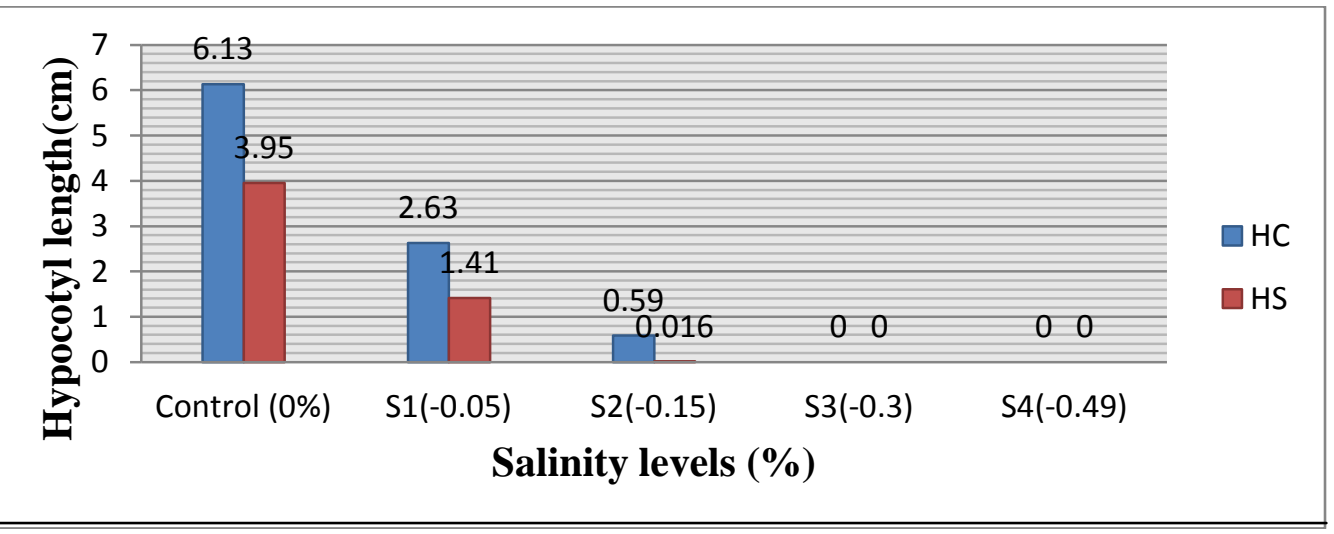

Graph4. Effect of different levels of salt stress on hypocotyl length of H.cannnabinus and H.sabdariffa

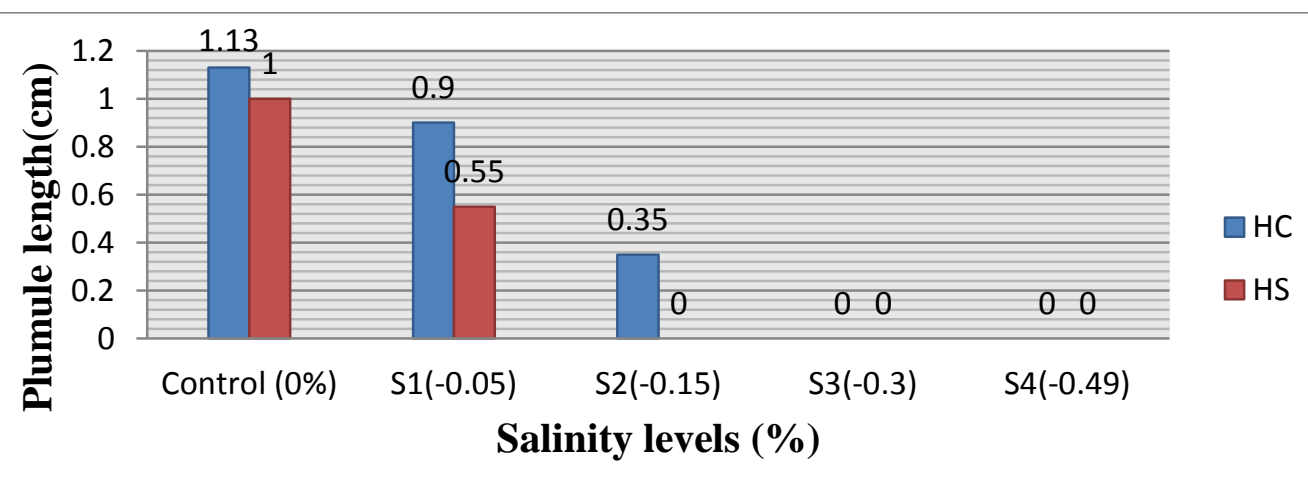

Graph5. Effect of different levels of salt stress on plumule length of H.cannnabinus and H.sabdariffa

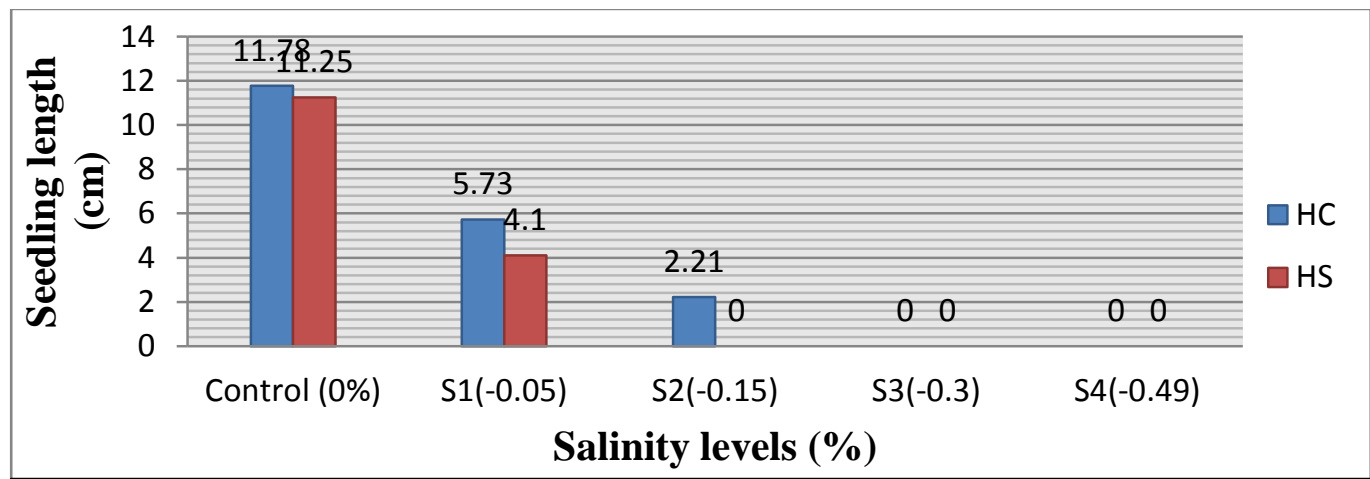

Graph6. Effect of different levels of salt stress on seedling length of H.cannnabinus and H.sabdariffa

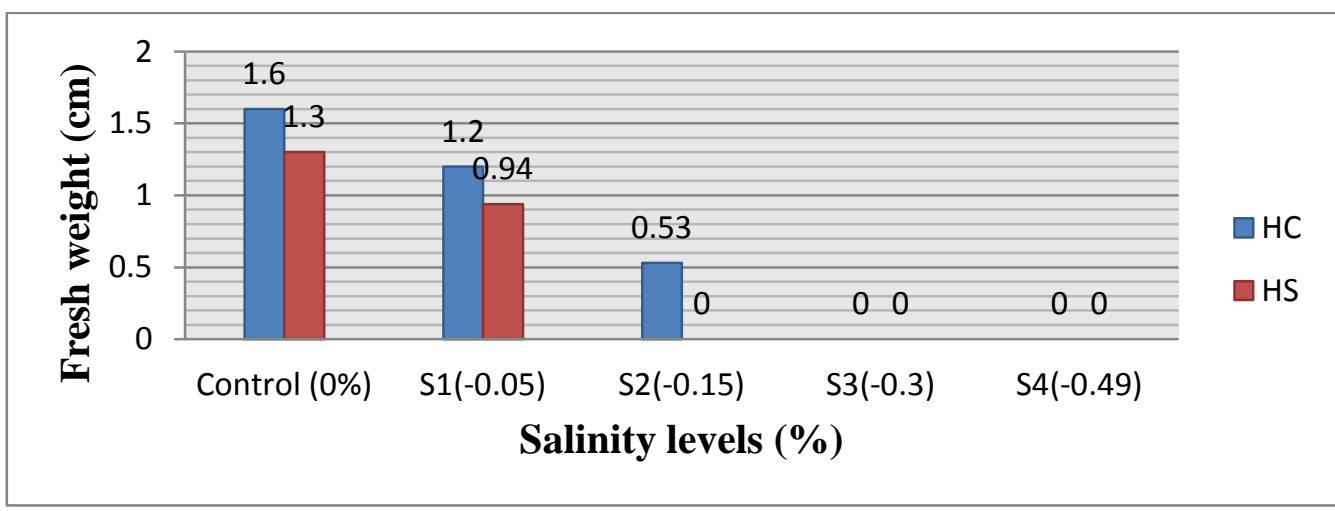

Graph7. Effect of different levels of salt stress on fresh weight of H.cannnabinus and H.sabdariffa 


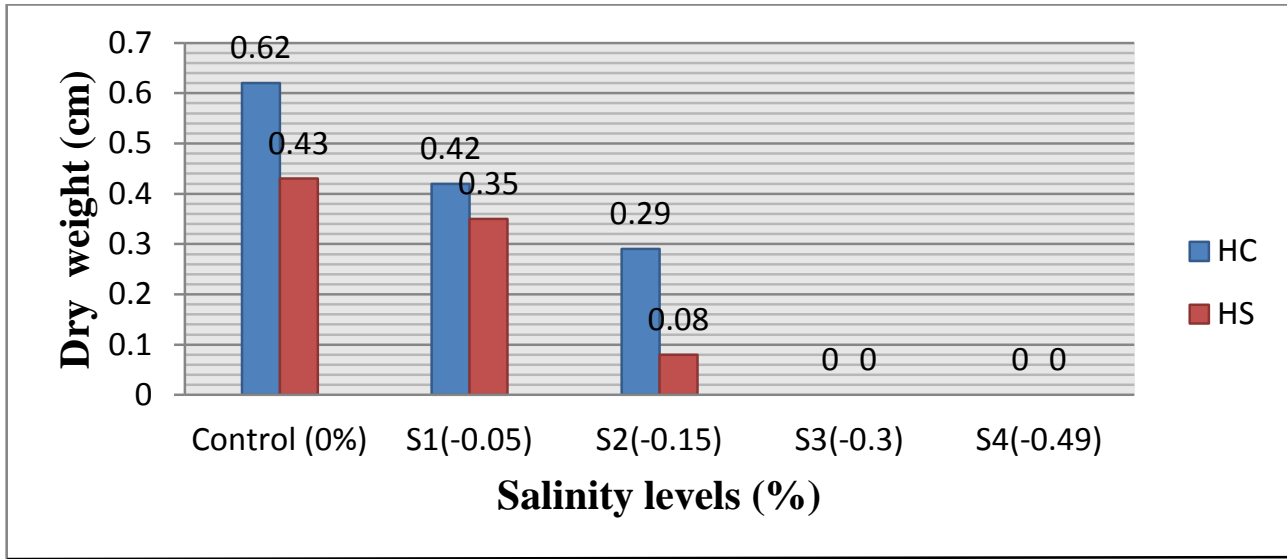

Graph8. Effect of different levels of salt stress on dry weight of H.cannnabinus and H.sabdariffa

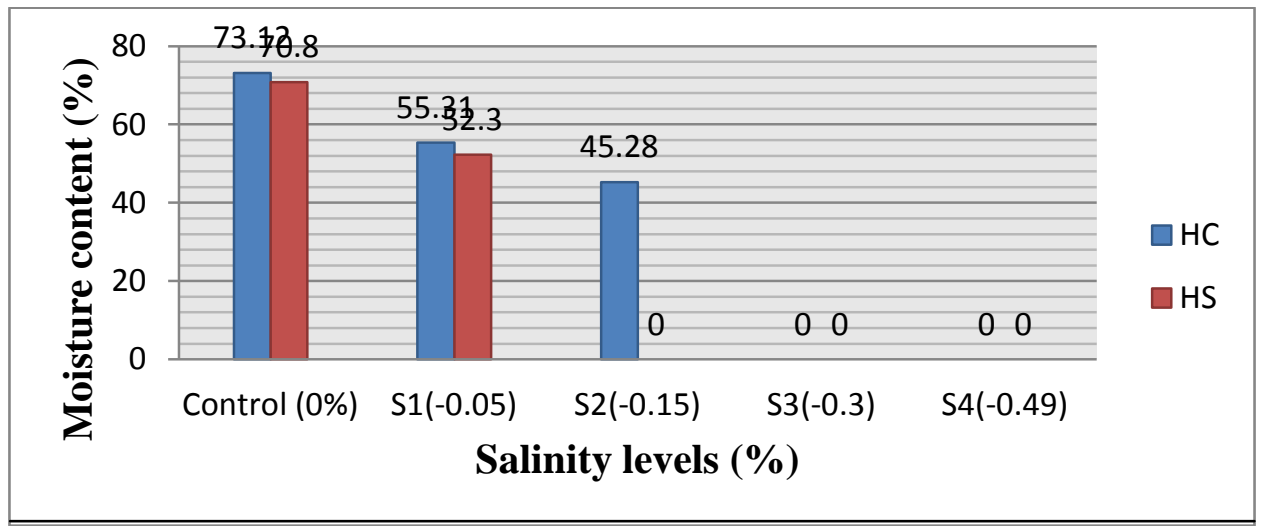

Graph9. Effect of different levels of salt stress on moisture content of H.cannnabinus and H.sabdariffa

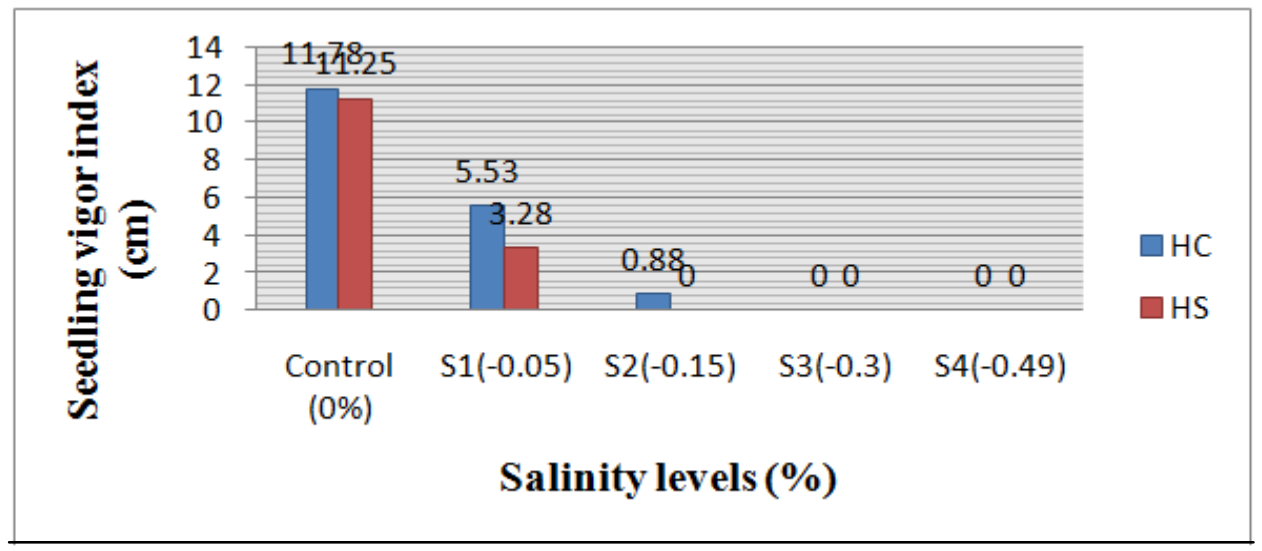

\section{Graph10. Effect of different levels of salt stress on seedling vigor index of H.cannnabinus and} H.sabdariffa

\section{Epilogue}

In the present study, salt stress adversely affected the rate of germination, germination percentage, seedling length, shoot length, moisture content, seed viability index, fresh wet and dry seedling weights of two Hibiscus species plants (Hibiscus cannabinus and Hibiscus sabdariffa). Overall, it seems that salinity through enhancement of osmotic pressure leads reduction of water absorbance and disturbance in metabolic and physiological processes will be under its effect. So, it cause more delay in germination following by enhancing seed germination duration. In total, it can be concluded that salinity stress significantly decreased all studied traits of two plants and the result indicates that the Hibiscus cannabinus is more resistant to salt stress when compared to that of Hibiscus sabdariffa. 


\section{References}

[1] Zhu \& J K, Plant salt tolerance, Trend Plant Science, 6 (2001) 66-71.

[2] Brady, N C and R R Weil, The Nature and Properties of Soils, $13^{\text {th }}$ edn, (New Jersey, Environmental Sciences) $2002,1192-1216$.

[3] Harris D, The effects of manure, genotype, seed priming, depth and date of sowing on the emergence and early growth of Sorghum bicolor Moench in semi-arid Botswana, Soil Till Res, 40(1996)73-88.

[4] Khajeh Hosseini, M, Powell A A and Bingham I J, The interaction between salinity stress and seed vigor during germination of soybean seeds, Seed Science and Technology, 31(2003)715-725.

[5] Almansouri M, J M Kinet and S Lutts, Effect of salt and osmotic stresses on germination in durum wheat (Triticum aestivum), Plant soil, 231(2001) 243-254.

[6] Murillo Amador B, R Lo’ pez-Aguilar, C Kaja, J Larrinaga Mayoral and A Flores-Herna'ndez, Comparative effects of NaCl and polyethylene glycol on germination, emergence and seedling growth of cowpea, J. Agron. Crop Sci, 188(2002).235-247.

[7] Bewley, D J \& Black M, Seeds: Physiology of development and germination, $2^{\text {nd }}$ edn, (Plenum Press, New York) 1994, 445 p.

[8] Seghatoleslami, M J, Effect of salinity on germination of Satureja hortensis (L), Cichorium intybus (L) and Cynara scolymus (L), Iranian Journal of Agricultural Researches, 8 (2010) 818-823.

[9] Sarmadnia Gh, Seed Technology (Jihad-e-Daneshgahi of Mashhad University Publications. Mashhad, Iran)1996, 288.

[10] Hudai Y and Arzu K, The influence of salinity on some vegetative and chemical changes of strawberries, African Journal of Biotechnology, 7(2008) 3299 - 3305.

[11] Younis M E, M N A Hasaneen, A R Ahmed and D M A El-Bialy, Plant growth, metabolism and adaptation in relation to stress conditions Reversal of harmful NaCl-effects in lettuce plants by foliar application with urea, Australian Journal of Crop Science, 2(2008) 83-95.

[12] Bor M, Ozdemir F and Turkan I, The effect of salt stress on lipid peroxidation and antioxidants in leaves of sugar beet Beta vulgaris L. and wild beet Beta maritime L, Plant Science, 164(2003)77 - 84.

[13] Neumann P M, Baluska F, M Ciamporova, O Gasparikova and Barlow P W, Inhabitation of root growth by salinity stress: Toxicity or an adaptive biophysical response, In: Structure and Function of Roots (the Netherlands: Kluwer Academic Publishers) 1995, 299304.

[14] Werner J E, Finkelstein R R, Arabidopsis mutants with reduced response to NaCl and osmotic stress, Physiologia Plantarum, 93(1995) 659 \pm 666 .

[15] Neumann P, Salinity resistance and plant growth revisited, Plant, Cell \& Environment, 20(1997)1193-1198.

[16] Katembe W J, I A Ungar and J P Mitchell, Effect of Salinity on germination and seedling growth of two Atriplex species (Chenopodiaceae), Annals of Botany, 82(1998) 167-175.

[17] Khodadad M, An evaluation of safflower genotypes (Carthamus tinctorius L.) seed germination and seedling characters in salt stress conditions, African Journal of Agricultural Research, 6(2011)1667-1672.

[18] Atak M, Kaya M D, Kaya G, Çıkılı Y and Çiftçi C Y, Effects of $\mathrm{NaCl}$ on the germination, seedling growth and water uptake of triticale, Turk J Agric For, 30(2006)39-47.

[19] Murillo Amador B and E Troyo-Die'guez, Effects of salinity on the germination and seedling characteristics of cowpea [Vigna unguiculata (L.) Walp.]. Aust J Exp Agric, 40(2000)433-438.

[20] Chauhan B \& Johnson D, Ecological studies on Cyperus difformis, Cyperus iria and Fimbristylis miliacea three troublesome annual sedge weeds of rice,Ann Appl Biol, 155(2009)103-112.

Ghazizade M, P Golkar and F Salehinejad, Effect of salinity stress on germination and seedling characters in safflower (Carthamus tinctorius L.) genotypes, Annals of Biological Research, 3(2012) 114-118.

[21] Kapoor R T, Salinity-Induced Changes in Germination, Biomass and Physiological Characteristics of Oryza sativa (L), International Conference on Advances in Biotechnology and Pharmaceutical Sciences, (2011) 208-210.

[22] Amiri M B, Rezvani Moghaddam P, Ehyai H R, Fallahi J and Aghhavani Shajari M, Effect of osmotic and salinity stresses on germination and seedling growth indices of artichoke (Cynara scoolymus) and purple coneflower (Echinacea purpurea), Environmental Stresses in crop sciences, 3(2010) 165-176. 